\title{
Effects of corpus luteum removal on progesterone, oestradiol-17 $\beta$ and LH in early pregnancy of the tammar wallaby, Macropus eugenii
}

\author{
T. P. Fletcher and M. B. Renfree \\ Department of Anatomy, Monash University, Melbourne, Victoria 3168, Australia
}

\begin{abstract}
Summary. The quiescent corpus luteum of female tammars was reactivated by removal of the pouch young (RPY). The reactivated corpus luteum was ablated 3 days after RPY. Plasma progesterone and oestradiol concentrations were measured by radioimmunoassay in these and in sham-operated controls. Excision of the CL abolished the rise in progesterone seen at Day 5-6 in the sham-operated animals $(130.7 \pm 56.6 \mathrm{vs}$ $452.4 \pm 176.0 \mathrm{pg} / \mathrm{ml}$, mean \pm s.d.). By contrast, oestradiol $-17 \beta$ values increased within $6-16 \mathrm{~h}$ of $\mathrm{CL}$ excision to $16 \cdot 3 \pm 6.9 \mathrm{pg} / \mathrm{ml}$ and remained high for $1-3$ days while in the sham-operated animals there were less sustained and more variable peaks of $10-20 \mathrm{pg} /$ $\mathrm{ml}$ between Days 3 and 5 (mean $12.0 \pm 3.6 \mathrm{pg} / \mathrm{ml}$ at Day $4-5$ ). We conclude that the early transient increase in peripheral plasma of progesterone is of luteal origin but the source of the oestradiol remains unknown.
\end{abstract}

Keywords: corpus luteum; progesterone; oestradiol-17ß; early pregnancy; marsupial

\section{Introduction}

It is generally recognized that the corpus luteum $(\mathrm{CL})$ is the main source of circulating progesterone in the tammar wallaby: luteal progesterone content and concentration rises during pregnancy concomitant with increase in size of the CL (Renfree et al., 1979). Peripheral plasma progesterone concentrations mirror the luteal concentrations and for the first 5 days of the cycle are $<200 \mathrm{pg} / \mathrm{ml}$ (Hinds \& Tyndale-Biscoe, 1982). There is a transient rise of progesterone of about $450 \mathrm{pg} / \mathrm{ml}$ lasting 1-2 days on Days 5-8 after removal of the pouch young followed by a return to basal levels. From Day 10 concentrations rise to around $500 \mathrm{pg} / \mathrm{ml}$ until parturition or oestrus.

This peak in vivo is reflected in in-vitro incubations of luteal tissue by an increased production rate at Day 5 after removal of pouch young (Hinds et al., 1983), and luteal tissue can synthesize progesterone from suitably labelled precursors at all stages of pregnancy (Renfree et al., 1984). Removal of the CL at Day 18 after removal of pouch young reduces plasma progesterone from 630 to $<200 \mathrm{pg} / \mathrm{ml}$ within $24 \mathrm{~h}$ (Findlay et al., 1983), and at Day 23 from about 600 to $<200 \mathrm{pg} / \mathrm{ml}$ (Harder et al., 1985).

The origin of circulating oestradiol-17ß during pregnancy is less clear. Whilst the post-partum rise in oestradiol from $<10$ to $20 \mathrm{pg} / \mathrm{ml}$ at oestrus is clearly of follicular origin (Shaw \& Renfree, 1984; Harder et al., 1984, 1985), there is also a transient rise to $16 \mathrm{pg} / \mathrm{ml}$ at around Day 5 after removal of pouch young when there are no developing follicles present (Shaw \& Renfree, 1984). A similar transient rise in oestradiol has been observed in early pregnancy in wild-shot animals with blastocysts reactivating after seasonal quiescence (Flint \& Renfree, 1982).

The increase in plasma oestradiol coinciding with the rise in progesterone at Day 5 suggests a luteal origin for the oestrogens also. This has been proposed by Evans et al. (1980) and Renfree $e t$ al. (1982), who observed that exogenous oestradiol but not progesterone or androstenedione could mimic the inhibition of follicular growth by the quiescent CL in tammars from which the CL had 
been removed. However, Renfree et al. (1984) could not detect aromatase in luteal tissue at Day 0 or between Days 11 and 25 after removal of pouch young, and CL contained only minute quantities of oestradiol. Likewise, the content of oestradiol in CL from mid- to late pregnant tammars was very low (Renfree et al., 1984; Shaw \& Renfree, 1984). The highest ovarian oestradiol content is found in ovaries with Graafian follicles (Harder et al., 1984; Shaw \& Renfree, 1984).

This study was designed to determine whether peripheral plasma progesterone and oestradiol during early pregnancy and the oestrous cycle in the tammar wallaby are of a luteal or non-luteal origin by removing the CL before the observed transient rises in these two hormones.

\section{Materials and Methods}

Animals. The tammars used in this study were part of a breeding colony established at Monash University with animals originally from Kangaroo Island, South Australia. Husbandry and handling were as previously described (Renfree \& Tyndale-Biscoe, 1978). The females were housed with males throughout this study.

Pouch young were removed (Day 0) from 11 lactating females to terminate quiescence at 09:00-10:00 $\mathrm{h}$ in March (i.e. during the breeding season). At 3 days after removal of young, the reactivated CL was removed from 6 tammars and another 5 were sham-operated as previously described (Young \& Renfree, 1979). Animals were checked at regular intervals from Day 25 to Day 80 (i.e. the period equivalent to 3 pregnant or oestrous cycles of 26-30 days each) for births and/or mating plugs.

Collection of blood samples. Blood samples of $4-5 \mathrm{ml}$ were taken from one of the lateral tail veins into heparinized syringes. The animals were bled daily from 2 days before removal of pouch young to Day 3 when blood was taken before and 4-6h after operation, at 8-h intervals from Day 3 to 6, twice on Day 7, and then daily to Day 13. Blood haematocrit showed no significant changes over the duration of the experiment so it was not necessary to replace the red cells. Plasma was separated by centrifugation and stored at $-20^{\circ} \mathrm{C}$ until assayed for progesterone, oestradiol and LH concentration by radioimmunoassays (RIA).

Hormone assays. The progesterone assay was that of Shaw \& Renfree (1984) re-validated as described below for antiserum S334 provided by Dr R. I. Cox (CSIRO Division of Animal Production, Prospect, NSW, Australia). The antiserum was raised against progesterone-11-hemi-succinate-bovine serum albumin and had the following percentage cross-reactivities: progesterone, $100 \% ; 11 \beta$-hydroxyprogesterone, $27 \% ; 17 \alpha$-hydroxyprogesterone, $0.3 \%$; $20 \alpha$-hydroxy-4-pregnene-3-one, $0.3 \% ; 20 \beta$-hydroxy-4-pregnene-3-one, $0.3 \% ;$ pregnenolone, $0.6 \% ; 3 \beta, 17$-dihydroxy-

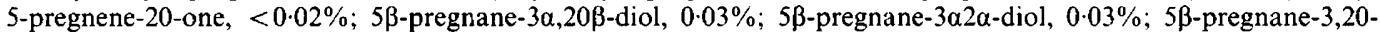
dione, $1.4 \%$; cortisol, $0.01 \%$; corticosterone, $5.8 \%$ and 11 -deoxycorticosterone, $6.9 \%$. Progesterone was measured by transferring $1 \mathrm{ml}$ plasma to $20-\mathrm{ml}$ screw-capped glass tubes with $8 \mathrm{ml}$ hexane (Analar, B.D.H. Australia, Port Fairy, Victoria) and shaking for $10 \mathrm{~min}$ on a horizontal tube shaker at about two $3 \mathrm{~cm}$ excursions/sec. The phases were allowed to separate and the aqueous layer was frozen in a bath of solid $\mathrm{CO}_{2} /$ ethanol. The hexane was decanted into $13 \times 100 \mathrm{~mm}$ test tubes and dried under a stream of dried, filtered air. The extracts were dissolved in $250 \mu \mathrm{l}$ of assay buffer $(0 \cdot 1 \mathrm{~m}$-phosphate, $\mathrm{pH} \mathrm{7.0}$; with $9 \cdot 0 \mathrm{~g} \mathrm{NaCl} / 1,1 \mathrm{~g}$ gelatin/l, $1 \mathrm{~g} \mathrm{NaN} / 1)$ and allowed to equilibrate for at least $4 \mathrm{~h}$. After equilibration, duplicate $0.1 \mathrm{ml}$ samples of the extract were assayed as described by Shaw \& Renfree (1984).

Efficiency of the extraction procedure was $75 \%$ as determined by recovery of radioactive progesterone equilibrated with plasma. Parallelism between standard and endogenous progesterone was determined by comparison of the buffer standard curve with a series of samples made by diluting a pool of plasma with high progesterone content with plasma previously treated with charcoal to remove endogenous steroids. Sensitivity of the assay, calculated as the lowest standard which differed from the zero standard by more than twice the standard deviation of the zero standard was $20 \mathrm{pg} / \mathrm{ml}$ for 4 assays. Accuracy was determined by addition of $0.5,1,3$ or $5 \mathrm{ng}$ progesterone to aliquants from a plasma pool which were extracted and assayed as described above. The average measured concentrations were within $10 \%$ of the expected values. Precision of the assay was evaluated by multiple determination of aliquants from 2 plasma pools included in every assay. The inter-assay coefficients of variation were $2.4 \%$ and $12.6 \%$ from 2 plasma pools in 4 assays, and intra-assay coefficient of variation was $12 \cdot 4 \%$. All samples from each animal were measured in the same assay.

Oestradiol was measured by the method of Shaw \& Renfree (1984), validated for tammar plasma, using antiserum S6181 provided by Dr R. I. Cox (CSIRO Division of Animal Production, Prospect, NSW, Australia). Efficiency of the extraction procedure was $92 \%$. Sensitivity of the assay was $4 \mathrm{pg} / \mathrm{ml}$. The inter-assay coefficients of variation were $8.76 \%$ and $9.4 \%$ for 2 plasma pools in 4 assays, and intra-assay coefficient of variation was $5.33 \%$. All samples from each animal were measured in the same assay.

Luteinizing hormone was measured by the heterologous double-antibody radioimmunoassay described by Sutherland et al. (1980) and validated for use with tammar plasma. The radio ligand was NIADDK rat LH-I-6 and the antibody was rabbit anti-ovine LH (GDN-15) purchased from Professor G. D. Niswender (Colorado State University, Fort Collins, CO, U.S.A.). The standard was NIH-oLH-S23. The assay sensitivity was $0.3 \mathrm{ng} / \mathrm{ml}$ and inter- and intra-assay coefficients of variation were $6.5(n=3)$ and $4.5 \%$ respectively. 


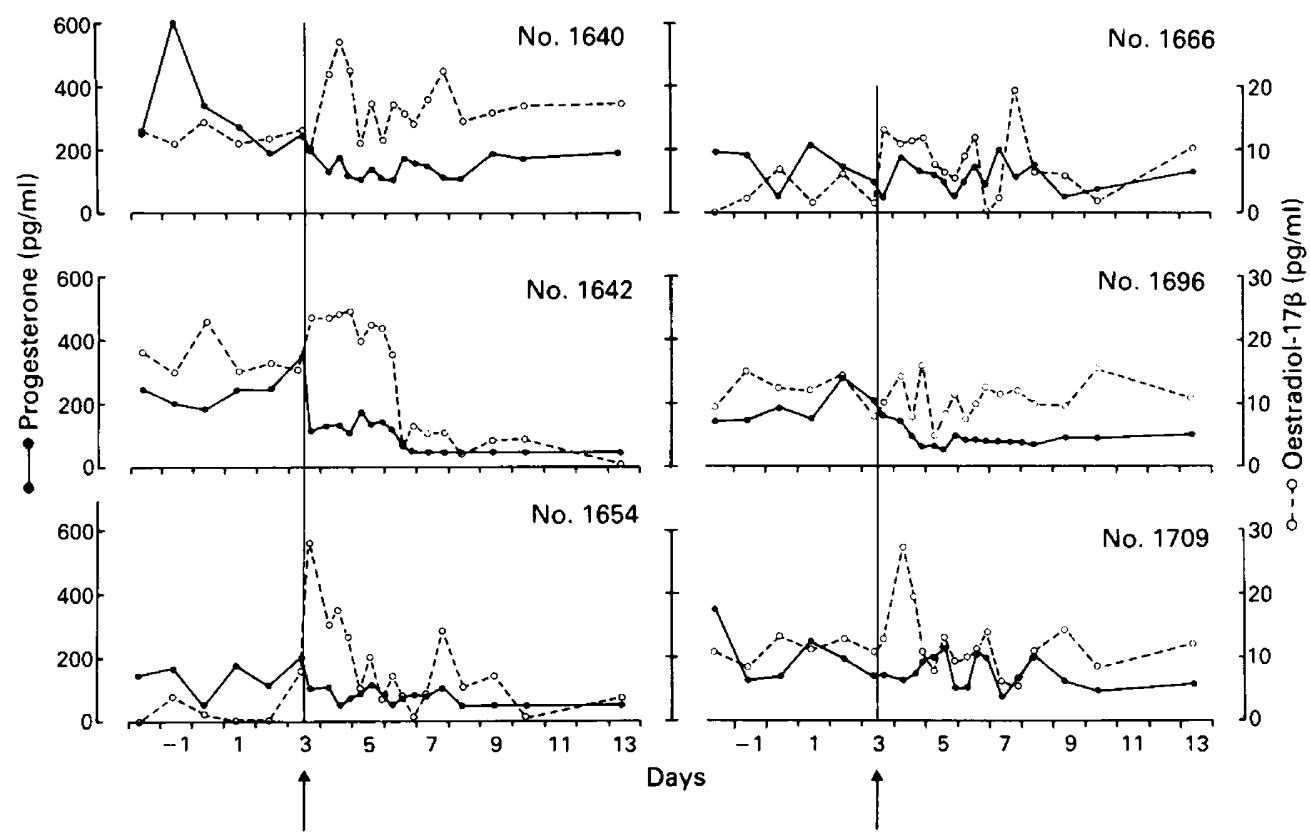

Fig. 1. Plasma concentrations of progesterone $(O)$ and oestradiol-17 $(O)$ in 6 tammars before and after ablation of the corpus luteum (arrow and vertical line on Day 3 ) reactivated by removal of the pouch young (RPY) on Day 0.

\section{Results}

\section{Progesterone concentrations}

The mean ( \pm s.d.) concentration of progesterone measured before removal of pouch young was $217 \cdot 1 \pm 107 \cdot 2 \mathrm{pg} / \mathrm{ml}(n=33)$ with transient (single sample) high values seen in 2 of the 11 animals. After excision of CL on the morning of Day 3 after removal of pouch young progesterone concentration fell by different amounts in 5 of 6 tammars and the mean concentration at the afternoon sample was $127 \mathrm{pg} / \mathrm{ml}$ (Fig. 1, Table 1). In the other animal plasma progesterone concentrations remained unchanged at the afternoon sample. Subsequently, progesterone concentrations remained low for the duration of the experiment and no animal without CL had an early peak in progesterone. In the sham-operated group there was no marked effect on progesterone on the day of operation. The early progesterone peak was observed in each animal of the sham-operated group with the peak occurring on Day 4 in one animal, on Day 7 in one animal, and on Days 5-6 in 3 animals (Fig. 2).

\section{Oestradiol concentrations}

The mean ( \pm s.d.) concentration of oestradiol measured before removal of pouch young was $10 \cdot 1 \pm 6.5 \mathrm{pg} / \mathrm{ml}(n=33)$ but with considerable between-animal variation. Oestradiol concentration rose to oestrous values $(16.3 \pm 6.9 \mathrm{pg} / \mathrm{ml})$ in 5 animals within $16 \mathrm{~h}$ of operation (Fig. 1). In the remaining animal (No. 1696) oestradiol rose by $16 \mathrm{~h}$ but not to the same extent (Fig. 1). Oestradiol values remained high for up to $48 \mathrm{~h}$ then declined but continued to fluctuate for several days. The mean oestradiol concentration in the sham-operated animals at Days 4-5 was $12.0 \pm 3.6 \mathrm{pg} / \mathrm{ml}$, but there were considerable fluctuations within and between animals, with a number of small peaks occurring during the period of thrice daily sampling (Fig. 2), so that only 2 (Nos 0770 and 1297) had a single marked peak. 


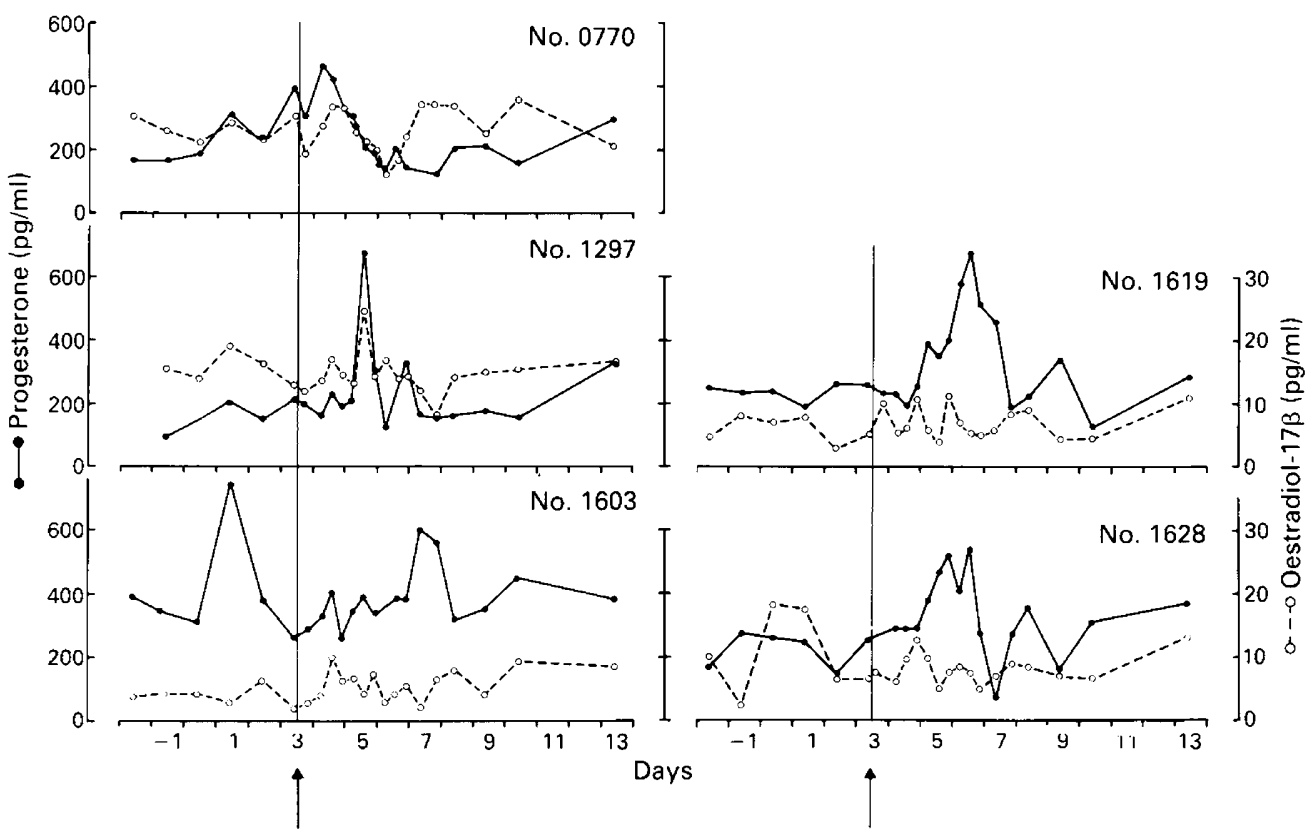

Fig. 2. Plasma concentrations of progesterone $(\Theta)$ and oestradiol-17 $\beta(O)$ in 5 tammars before and after sham excision (arrow and vertical line on Day 3 ) of the corpus luteum reactivated by removal of the pouch young on Day 0 .

Table 1. Mean ( \pm s.d.) progesterone, oestradiol-17ß and LH concentrations measured immediately before CL excision (CL-X) or sham operation on Day 3 after removal of the pouch young, on the afternoon of Day 3 and early morning of Day 4

\begin{tabular}{|c|c|c|c|c|c|c|c|}
\hline & & \multicolumn{2}{|c|}{ Progesterone } & \multicolumn{2}{|c|}{ Oestradiol-17 $\beta$} & \multicolumn{2}{|c|}{ LH } \\
\hline \multicolumn{2}{|c|}{ Sample } & Sham & CL-X & Sham & CL-X & Sham & CL-X \\
\hline Day 3 & $\begin{array}{l}10: 00 \mathrm{~h} \\
16: 00 \mathrm{~h}\end{array}$ & $\begin{array}{l}277 \cdot 1 \pm 63 \cdot 2 \\
258 \cdot 5 \pm 36 \cdot 6\end{array}$ & $\begin{array}{l}207 \cdot 2 \pm 79 \cdot 3 \\
127 \cdot 3 \pm 45 \cdot 2\end{array}$ & $\begin{array}{l}8 \cdot 4 \pm 5 \cdot 0 \\
8 \cdot 4 \pm 3 \cdot 1\end{array}$ & $\begin{array}{r}9.4 \pm 4.3 \\
16.3 \pm 6.9\end{array}$ & $\begin{array}{l}0.48 \pm 0.42 \\
0.37 \pm 0.25\end{array}$ & $\begin{array}{l}2.11 \pm 2.46 \\
0.65 \pm 0.68\end{array}$ \\
\hline Day 4 & $06: 00 \mathrm{~h}$ & $295 \cdot 1 \pm 101 \cdot 3$ & $137 \cdot 4 \pm 22 \cdot 3$ & $8.6 \pm 4.1$ & $18.9 \pm 5.9^{*}$ & $0.21 \pm 0.06$ & $0 \cdot 70 \pm 0.80$ \\
\hline
\end{tabular}

Each post-treatment value within groups was tested for significant differences from the pre-operation value by Student's $t$ test for paired samples (Schefler, 1979).

*Significantly different from the pre-operation value, $P<0.01$.

\section{$L H$ concentrations}

The mean ( \pm s.d.) concentration of LH measured before operation was $1 \cdot 1 \pm 1 \cdot 1 \mathrm{ng} / \mathrm{ml}$ $(n=13)$ (Fig. 3): one animal (No. 1654) had a very high $\mathrm{LH}$ value $(4.8 \mathrm{ng} / \mathrm{ml})$ before removal of pouch young and was the source of most of the variation around the mean. With this animal eliminated from the data the basal pre-operative LH concentration was $0.9 \pm 0.4 \mathrm{ng} / \mathrm{ml}(n=12)$ which was comparable with $0.52 \pm 0.34 \mathrm{ng} / \mathrm{ml}$ in the sham-operated animals. Tammar 1654 also had the lowest concentrations of oestradiol-17 $\beta$ of any animal in the experiment. Sham-operated animals showed no change in LH concentration after operation but in all animals from which 


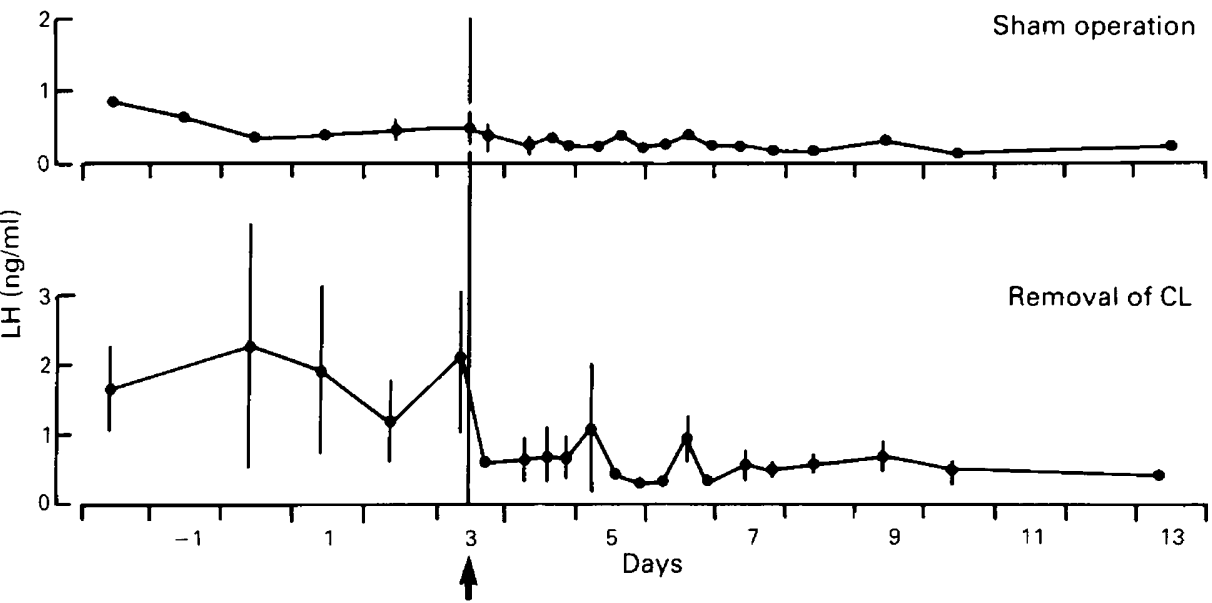

Fig. 3. Plasma concentrations of $\mathrm{LH}(\mathrm{NIH}-\mathrm{oLH}-23)$ in tammars before and after excision of the $\mathrm{CL}(\mathrm{N}=6)$ and sham excision $(\mathrm{N}=5)$ of the corpus luteum reactivated by removal of the pouch young (RPY) on Day 0 . The time of operation is indicated by the vertical line. Values are mean \pm s.e.m.; error bars are not shown when less than the size of the symbol.

the $\mathrm{CL}$ had been excised LH concentration declined within $6 \mathrm{~h}$ and remained low with some fluctuations for the duration of the experiment (Fig. 3).

\section{Resumption of reproductive activity}

In the sham-operated group $4 / 5$ animals had pouch young on Day 36. By back dating from pouch young estimated ages, the day of birth was between Day 27 and Day 30, which is within the normal range. The remaining animal did not give birth but had a mating plug at the same time, also within the expected time. In the experimental group 2 tammars had new pouch young on Day 45 (Nos 1696 and 1709) and another two on Day 52 (Nos 1654 and 1666). By subtracting the period of 29 days from oestrus to birth (Merchant, 1979), it appears that the new ovulations occurred 16-23 days after removal of CL. New pouch young or a mating plug were not detected in the remaining 2 animals by Day 80 after removal of pouch young.

\section{Discussion}

The transient increases in peripheral plasma progesterone and oestradiol at Days 5-7 previously reported (Hinds \& Tyndale-Biscoe, 1982; Shaw \& Renfree, 1984) were also observed in this study. However, oestradiol concentrations were more variable in individual animals, and the mean of $12.0 \pm 3.6 \mathrm{pg} / \mathrm{ml}$ does not accurately reflect the fluctuations which appear with the increased frequency of sampling. The mean rise is less than that of $16 \mathrm{pg} / \mathrm{ml}$ reported by Shaw \& Renfree (1984) and a clear-cut peak at around Days 4 or 5 was only observed in 2 animals. Excision of $C L$ at Day 3 after removal of pouch young abolished the rise in progesterone seen at Day 5-6 in the shamoperated animals $(130.7 \pm 56.5 \mathrm{pg} / \mathrm{ml} v s 452.4 \pm 176.0 \mathrm{pg} / \mathrm{ml})$, but did not depress the circulating oestradiol values. After removal of CL, there was a rapid $(6-16 \mathrm{~h})$ increase in plasma oestradiol from $<10 \mathrm{pg} / \mathrm{ml}$ to $16 \cdot 3 \pm 6 \cdot 9 \mathrm{pg} / \mathrm{ml}$ (Table 1), and the rise was sustained for $2-3$ days.

These results confirm that the corpus luteum is responsible for the increases in peripheral plasma progesterone during early as well as late pregnancy, and also show that the increase in production rate of progesterone by luteal tissue in vitro (Hinds et al., 1983) is reflected in vivo. However, the oestradiol in peripheral plasma cannot be of luteal origin. 
These results support the findings from in-vitro incubations of luteal tissue with suitable radioactive precursors, in which progesterone but not oestradiol can be detected (Renfree $e t$ al., 1984). Furthermore, although luteal tissue contains oestradiol and oestrone, albeit in small quantities ( $<100 \mathrm{pg}$ ) (Renfree et al., 1984; Shaw \& Renfree, 1984), from the present results it is clear that this luteal oestrogen is not the source of the observed transient rise.

Paradoxically, the quiescent corpus luteum of diapause is able to prevent early follicular development while it itself is inhibited by the sucking stimulus. Removal of the CL leads to a new ovulation 15-18 days later (Tyndale-Biscoe \& Hawkins, 1977). The time taken to ovulate after CL excision in the present study was slightly longer (16-23 days). Since inhibition of follicular development may be mimicked by administration of physiological doses of oestradiol-17 $\beta$ (but not progesterone) after CL removal (Evans et al., 1980; Renfree et al., 1982) by a negative feedback of oestradiol on the hypothalamic-pituitary axis (Horn et al., 1985), it is possible that the rise in oestrogen after surgery temporarily inhibited immediate resumption of the events leading to follicular maturation in some animals. However, sham operation on Day 3 did not affect oestrogen concentrations (Table 1), nor did it influence the time of birth, confirming previous detailed results (Young \& Renfree, 1979).

The tammar adrenal gland has aromatase activity (Callard et al., 1982), as does the ovarian cortex (Renfree et al., 1984), with highest oestradiol concentrations being found in ovaries with Graafian follicles (Harder et al., 1984). Although ovaries at Day 0 contain oestradiol (Shaw \& Renfree, 1984), follicles on Day 3 after removal of pouch young are small, and since oestradiol values of $12.7 \mathrm{pg} / \mathrm{ml}$ are found after ovariectomy (Flint \& Renfree, 1982), it seems possible that the immediate increase in circulating oestradiol after excision of the $\mathrm{CL}$ is of adrenal origin.

The exact role of the transient rises in both progesterone and oestradiol at Days 5-7 remains unclear. Uterine metabolic reactivation is measurable at Day 4 after removal of pouch young (Shaw \& Renfree, 1986), and blastocyst metabolism increases by Day 5 (Thornber et al., 1981; Shaw \& Renfree, 1986). The initiation of uterine and embryonic metabolism after diapause has therefore already occurred by the time the transient rises are observed. Furthermore, while exogenous progesterone alone can reactivate and support embryonic development (Renfree \& TyndaleBiscoe, 1973), oestradiol in pharmacological (Smith \& Sharman, 1969) or physiological doses (Fletcher et al., 1988) does not. It is possible that initiation of development after diapause may be due to the earlier, although very variable, increases in plasma progesterone and oestradiol observed in this study. Once diapause has ended, either or both steroids may be the essential signals for the maintenance of early development because removal of the corpus luteum before Day 8 after removal of pouch young results in embryonic loss and failure of the pregnancy (Tyndale-Biscoe, 1963, 1970).

We conclude that the early transient rise of progesterone is of luteal origin, consistent with the in-vitro data. A consistent rise in oestradiol-17 $\beta$ was not demonstrated in this study, despite 8-h sampling intervals on Days 3-6. Perhaps only low, fluctuating levels of oestrogen are required in concert with the progesterone peak for reactivation. The relative importance of these two steroids in early pregnancy of the tammar remains unclear.

We thank D. Blanden, Dr K. Gordon and Dr G. Shaw for assistance with collecting blood samples and Dr G. Shaw for helpful discussions of the manuscript. This study was supported by Australian Research Grants Scheme Program Grant A1851504P and permit No. 84-28 from Department of Conservation, Forests and Lands, Victoria, Australia.

\section{References}

Callard, G.V., Petro, Z. \& Tyndale-Biscoe, C.H. (1982) Aromatase activity in marsupial brain, ovaries and adrenals. Gen. comp. Endocrinol. 46, 541-546.

Evans, S.M., Tyndale-Biscoe, C.H. \& Sutherland, R.L.
(1980) Control of gonadotrophin secretion in the female tammar wallaby (Macropus eugenii). $J$. Endocr. 86, 13-23.

Findlay, L., Ward, K.L. \& Renfree, M.B. (1983) 
Mammary gland lactose, plasma progesterone and lactogenesis in the marsupial Macropus eugenii. $J$. Endocr. 97, 425-436.

Fletcher, T.P., Jetton, A.E. \& Renfree, M.B. (1988) Influence of progesterone and oestraodiol-17 $\beta$ on blastocysts of the tammar wallaby (Macropus eugenii) during seasonal diapause. J. Reprod. Fert. 83, 193-200.

Flint, A.P.F. \& Renfree, M.B. (1982) Oestradiol-17 $\beta$ in the circulation during seasonal activation of the diapausing blastocyst in a wild population of tammar wallabies, Macropus eugenii. J. Endocr. 95, 293-300.

Harder, J.D., Hinds, L.A., Horn, C.A. \& Tyndale-Biscoe, C.H. (1984) Oestradiol in follicular fluid and in uteroovarian venous and peripheral plasma during parturition and post-partum oestrus in the tammar, Macropus eugenii. J. Reprod. Fert. 72, 551-558.

Harder, J.D., Hinds, L.A., Horn, C.A. \& Tyndale-Biscoe, C.H. (1985) Effects of removal in late pregnancy of the corpus luteum, Graafian follicle or ovaries on plasma progesterone, oestradiol, LH, parturition and post-partum oestrus in the tammar, Macropus eugenii. J. Reprod. Fert. 75, 449-459.

Hinds, L.A. \& Tyndale-Biscoe, C.H. (1982) Plasma progesterone levels in the pregnant and non-pregnant tammar, Macropus eugenii.J. Endocr. 93, 99-107.

Hinds, L.A., Evans, S.M. \& Tyndale-Biscoe, C.H. (1983) In-vitro secretion of progesterone by the corpus luteum of the tammar wallaby, Macropus eugenii. $J$. Reprod. Fert. 67, 57-63.

Horn, C.A., Fletcher, T.P. \& Carpenter, S. (1985) Effects of oestradiol-17 $\beta$ on peripheral plasma concentrations of $\mathrm{LH}$ and $\mathrm{FSH}$ in ovariectomized tammars (Macropus eugenii). J. Reprod. Fert. 73, 585-592.

Merchant, J.C. (1979) The effect of pregnancy on the interval between one oestrus and the next in the tammar wallaby, Macropus eugenii. J. Reprod. Fert. $56,459-463$.

Renfree, M.B. \& Tyndale-Biscoe, C.H. (1973) Intrauterine development after diapause in the marsupial, Macropus eugenii. Devl Biol. 32, 28-40.

Renfree, M.B. \& Tyndale,-Biscoe, C.H. (1978) Manipulation of marsupial embryos and pouch young. In Methods in Mammalian Reproduction, Ch. 15, pp. 307-331. Ed. J. C. Daniel. Academic Press, New York.

Renfree, M.B., Green, S.W. \& Young, I.R. (1979) Growth of the corpus luteum and its progesterone content during pregnancy in the tammar wallaby, Macropus eugenii. J. Reprod. Fert. 57, 131-136.

Renfree, M.B., Wallace, G.I. \& Young, I.R. (1982)
Effects of progesterone, oestradiol- $17 \beta$ and androstenedione on follicular growth after removal of the corpus luteum during lactational and seasonal quiescence in the tammar wallaby. J. Endocr. 92, 397-403.

Renfree, M.B., Flint, A.P.F., Green, S.W. \& Heap, R.B. (1984) Ovarian steroid metabolism and luteal oestrogens in the corpus luteum of the tammar wallaby. $J$. Endocr. 101, 231-240.

Schefler, W.C. (1979) Statistics for the Biological Sciences. Addison-Wesley Publishing Company, Reading, Massachusetts.

Shaw, G. \& Renfree, M.B. (1984) Concentrations of oestradiol-17 $\beta$ in plasma and corpora lutea throughout pregnancy in the tammar, Macropus eugenii. $J$. Reprod. Fert. 72, 29-37.

Shaw, G. \& Renfree, M.B. (1986) Uterine and embryonic metabolism after diapause in the tammar wallaby, Macropus eugenii. J. Reprod. Fert. 76, 339-347.

Smith, M.J. \& Sharman, G.B. (1969) Development of dormant blastocysts induced by oestrogen in the ovariectomized marsupial, Macropus eugenii. Aust.J. biol. Sci. 22, 171-180.

Sutherland, R.L., Evans, S.M. \& Tyndale-Biscoe, C.H. (1980) Macropodid marsupial luteinising hormone: validation of assay procedures and changes in plasma levels during the oestrous cycle in the female tammar wallaby (Macropus eugenii). J. Endocr. 86, 1-12.

Thornber, E.J., Renfree, M.B. \& Wallace, G.I. (1981) Biochemical studies of intrauterine components of the tammar wallaby, Macropus eugenii, during pregnancy. J. Embryol. exp. Morph. 62, 325-338.

Tyndale-Biscoe, C.H. (1963) The role of the corpus luteum in the delayed implantation in marsupials. In Delayed Implantation, pp. 15-32. Ed. A. C. Enders. Chicago University Press.

Tyndale-Biscoe, C.H. (1970) Resumption of development by quiescent blastocysts transferred to primed, ovariectomised recipients in the marsupial, Macropus eugenii. J. Reprod. Fert. 23, 25-32.

Tyndale-Biscoe, C.H. \& Hawkins, J. (1977) The corpora lutea of marsupials: Aspects of function and control. In Reproduction and Evolution, pp. 245-252. Eds J. H. Calaby \& C. H. Tyndale-Biscoe. Australian Academy of Science, Canberra.

Young, I.R. \& Renfree, M.B. (1979) The effects of corpus luteum removal during gestation on parturition in the tammar wallaby (Macropus eugenii). J. Reprod. Fert. 56, 249-254. 